\title{
Development of methods for analyzing the economic activities of legal service enterprises
}

\author{
Egor Viktorovich Parakhin* \\ Rostov State Economic University (RINKH), Rostov-on-Don, Russia
}

\begin{abstract}
The article reveals the features of the economic analysis of legal service enterprises. The key assets of enterprises of this type are formed by intangible assets - the competence of specialists in the field of law, their experience and reputation. For the accounting and analysis of these values, the concept of reputation-competence capital is formulated, which is considered as a set of assets of an enterprise that provides legal services, ensuring the quality of services and their competitiveness. The complexity of assessing such characteristics of service as reputation and competence leads to use of relative indicators formed by an expert and expressed in points. The analytical potential of these assessments is limited, but their formation is extremely important for management of enterprises that provide legal services, since it allows to select the optimal options for development of legal services considering the increase in intangible assets related to reputation and competence capital.
\end{abstract}

\section{Introduction}

Provision of legal services accompanies the entire history of formation and development of civil institutions in society. However, despite the fact that provision of legal services has a long history, the forms of their provision remain largely conservative. Thus, the predominant forms of rendering legal services are individual services in the form of obtaining legal services or provision of legal services by organizations consisting of several lawyers or lawyers of other specialties. Customer service is carried out in the process of personal contact, the main work is the preparation of documents and their submission to various legal institutions.

Compared to the complex technological activities in industry, agriculture, infrastructure, network services and other sectors of the economy, the business of providing legal services can be mistakenly perceived as simple in the organization, and open to analysis. So, if we consider the work of an individual lawyer, then the income he/she receives from servicing the customer and the time spent on providing the service allow to assess the effectiveness of the work, its profitability and other economic parameters of the activity. Such assessments will be logically correct, but they will not allow a

\footnotetext{
* Corresponding author: svetlana-06-84@yandex.ru
} 
comprehensive analysis of economic activity in the field of legal services, since the analysis shall not only measure individual phenomena and processes of economic life, but also allow to identify its cause-and-effect relationships, to establish patterns of development of a law firm. Therefore, to study the economic content of legal services, it is not enough to assess its profitability and costs - it is necessary to investigate the sources and resources that make it possible to provide high-quality and complete legal services, to determine the areas of investment in the development of legal services.

To solve these problems, it is necessary to expand the system of indicators for the analysis of economic activity, supplement it with assessments characterizing those assets of the enterprise, the functioning of which directly affects the scale and quality of provision of legal services. The process of providing legal services itself must be considered not just as the result of the efforts of an individual (even if the services are provided by one specialist personally), but as a result of the work of a business entity - an enterprise. Use of the category "enterprise" to designate a producer of legal services focuses on the processes of formation of an economic result through use of material, personnel, information, financial and other resources of a business entity. An individual lawyer or a law firm can be considered as an enterprise of legal services - regardless of the subject composition, such an enterprise implements the entire technological cycle of legal services, which is necessary for research as part of an economic analysis of the processes of providing legal services. This approach is used for the first time, but it is the basis for integration of traditional and specially developed methods of researching economic activity in the field of legal services.

\section{Study Methods}

The methodological basis of the study was formed by the methods of economic analysis of service processes and the assessment of the efficiency of enterprises functioning in the service sector. We used both traditional methods of analyzing economic activity, which allow assessing the efficiency of using the resources of an enterprise: material, commodity, financial, personnel, information, as well as specific assessments reflecting the peculiarities of the functioning of business service enterprises, which include legal service organizations.

Specific economic assessments of legal activities are based on the study of the features of the technological process of providing legal services. It is important to emphasize that production and technological processes of law firms differ in composition and structure from the activities of enterprises in other sectors of the economy. The material component of the production and technological activities of law firms is much less informational. So, as a key technological process of a law firm, one can single out information exchange (in the form of workflow) between the customer and other participants in legal relations, as a result of which the customer's legal status changes (gaining new rights, changing legal status, defending violated rights, and etc.), which is the result of provision of legal services. The workflow itself is carried out as a result of a qualified legal analysis of the initial data, existing legal norms and information obtained in the course of the trial of the customer's case, as well as in interaction with a wide range of third parties (other civil parties to the proceedings, supervisory and regulatory bodies, and etc.) that affect legal status of the customer. The technology of this process differs from the traditional production stages of the release of material products, which requires clarification of the techniques and methods for analyzing economic activity in this area.

The technology of legal services does not depend on the scale of attracting specialists and is structurally different from traditional industrial and commercial activities - in the system of legal services, the key element is legal operations, performance of which 
practically does not depend on whether they are performed by a specialist individually or as part of a group, which hides the role and significance the production system itself for provision of legal services as a specialized organization with its own technological process, using resources to obtain the planned results.

Techniques and methods for analyzing economic activities in the field of legal services shall allow assessing the effectiveness of each stage of provision of legal services, the rationality of using resources, and the effectiveness of all work with customers. Methods for the analysis of economic activity in the legal sphere shall make it possible to assess not only its financial results, but also the change in the assets of the enterprise, for which it is necessary to use the methods of assessing both tangible and intangible assets.

To assess the scale of economic activity in the field of legal services, the study used methods of statistical analysis, as well as expert assessments of the quality and effectiveness of the provision of legal services.

When performing investment modeling, financial calculations were carried out in order to choose the best option for investing in development of the capital of a legal service company.

\section{Study Results}

The main result of the study is formation of a set of techniques for analyzing key intangible assets of legal service enterprises, ensuring competitiveness and long-term financial stability of economic activity.

Capital funds are considered as the key assets of a legal service company, the operation of which ensures the key characteristics of activities in this area - competence and trust in a law firm. These intangible aspects of the service process are leading for legal activities and are considered as the reputation and competence capital of the legal service company.

This type of capital is one of the forms of intellectual capital, the conceptual understanding of which took shape in the scientific references at the end of the twentieth century and is actively developing now [15], [16], [22], [29], [31]. Also, allocation of reputation and competence capital is development of the already developed in economic theory and practice of the study of goodwill [18], [23] - intangible resources that are not amenable to an unambiguous financial assessment, but are the sources of the company's competitiveness.

The main assets of a legal service enterprise that ensure its competence are the knowledge and skills of specialists, their ability to perform all the required procedural actions and documentary operations. The technical equipment of specialists is also important, which requires accounting and analysis of technical and informational means as important assets of a legal service enterprise. The assets that affect the competence of the enterprise can include organizational mechanisms that ensure the sustained and timely execution of all customer service operations. The economic analysis of this type of assets is closest to the assessment of the production, technical and qualification characteristics of an enterprise; it can be based on use of existing indicators of provision of performers with technical means, personnel of the required qualifications, as well as permits, licenses and other intangible assets.

In market conditions, it is not enough to have only the means of producing products or providing services. Without connections with consumers, even the best specialists will not be able to implement their competence, therefore, the technology of interaction with consumers is also a firm's capital, which is expressed in its reputation. Reputational resources are the most difficult to assess, despite the fact that quite a lot of attention has been paid to them recently and various approaches to accounting and analysis of this type of assets are being developed [9], [10], [11], [17], [19], [21], [26], [33]. 
In general, the following definition can be given: "Reputation and competence capital is a set of tangible and intangible assets of an enterprise, the operation of which ensures provision of high-quality competitive services, the achievement of innovative results in legal activities".

Assets of reputation and competence capital can be measured in kind (the number of licenses, the level of qualifications of specialists, and etc.), conditional (points, indices, and etc.) and value terms. The key characteristic of these assets is that they do not just take part in the operation of the enterprise, but they are a source of additional value, increasing the quality of services in comparison with existing offers on the market and provide an opportunity to offer customers unique services. These assets include both technical means of service, including buildings and premises, telecommunication systems that allow to provide a comfortable service, and intangible means - licenses and patents, which provide the right to carry out certain activities, and the competence and qualifications of employees who are able to solve complex problems in the course of customer service.

The processes of development of reputation and competence capital reflect the key cause-and-effect relationships and patterns of functioning of the legal service enterprise, their study makes it possible to clarify the composition and direction of economic analysis of this type of economic systems. The results of the exploitation of reputation and competence capital are the achievement of the following effects:

1) attracting customers;

2) provision of quality services;

3) achieving customer satisfaction from teamwork;

4) improvement of the regulatory and legal mechanisms of society considered as the highest result of legal activity.

Achievement of these effects presupposes the most efficient implementation of all technological components of a legal service enterprise in order to solve complex professional problems. Accordingly, the qualification parameters of each technological operation, as well as the effectiveness of interaction with customers and counterparties, shall be considered and expressed in the form of an assessment of use of the company's reputation and competence capital. The economic analysis of a legal service enterprise considering the exploitation of its reputation and competence capital, combines both traditional methods of assessing the composition and structure of fixed assets, labor, and other assets, as well as new approaches to the analysis of performance results - both service effects reflecting the completeness of solving problems and the quality of service, customers, and social effects in the form of an impact on the state of the entire legal system.

Techniques and methods for assessing this type of capital are based on the methods used for the assessment and analysis of intangible assets and goodwill [27], [30], [32], but are integrated with financial and production and technical indicators.

The indicators of reputation and competence capital complement the existing assessments of intangible assets considering the following:

- parameters of the reputation of the legal service company: customer satisfaction, company recognition, trust in the organization;

- characteristics of competence: provision of technical means, the level of qualifications of specialists, the proportion of complex cases, the achievement of legal innovations in the process of providing services.

The analysis of the technical aspects of provision of services - provision of modern means of performers - can be carried out on the basis of traditional indicators for assessing the capital-labor ratio.

Customer satisfaction, visibility and credibility of the company are studied using a system of marketing research. 
These methods are developed quite fully for business service firms and can be used in full when assessing the corresponding assets of the reputation and competence capital of a legal service company.

The most difficult component of the reputation and competence capital of a legal service enterprise is the analysis of the level of its competence.

For legal activities, the main indicators for assessing the qualifications of specialists are: experience, number of cases, the presence of legal innovations. To form a single indicator of these parameters, it is offered to evaluate them according to a specially developed scale in points using an expert method. Comparison of the scores of an individual specialist with the highest possible estimates of seniority and the number of cases reflects the skill level of the personnel. Presence of legal innovations must be assessed very highly, therefore, if a specialist has them in his/her asset, then his/her qualifications shall also be assessed highly, regardless of the length of service and the number of cases. It shall be noted that the classification of legal work according to the degree of complexity does not yet have a uniform assessment and it is offered to evaluate the increased complexity of legal work with additional points if it contains one of the following characteristics: the case has been judged by several instances; a number of specialized examinations were used; the proceedings are conducted in related branches of law. If in the course of a specific case a legal innovation is achieved and a precedent is formed that can affect the state of the rule of law, then, of course, this work is considered as complex.

Use of the above estimates makes it possible to analyze the structure of the qualification component of the reputation and competence capital of a legal service enterprise by determining the proportion of highly qualified specialists in the total number of employees. That is, the offered accounting of complex cases and the identification of legal innovations reflects the significant results of provision of legal services and characterizes not only individual specialists, but also a legal enterprise as a whole, allowing to form such an indicator as an index of reputation and competence capital.

The offered reputation and competence indicators are expressed in relative terms, which allows them to be analyzed economically in conjunction with financial assessments. For this, index indicators are formed, which can be analyzed together with various financial indicators, which are percentage estimates of various economic characteristics and weighted considering their role and significance for the economic activity of the enterprise.

Namely, the method of multivariate comparative analysis is applicable, based on the method of Euclidean distances, which makes it possible to compare not only the absolute values of the indicators of each enterprise, but also the degree of their proximity to the reference indicators. For this, indicators of reputation and competence capital form a single data matrix with traditional financial indicators, such as: cost-effectiveness; financial stability; autonomy coefficient; service rhythm index.

As a result of bringing the indicators to unity with the clarification of the influence of each characteristic on the process of comparative analysis by weighting coefficients established by expert means, a matrix of indicators is formed, which makes it possible to rank and compare the economic activities of various law firms. Such a comparative analysis allows the management of a legal service company to select the most promising and effective options for investing in the development of systems for provision of legal services.

\section{Discussion of Results}

Developments presented in the scientific references on the analysis of economic activities are more focused on assessing the efficiency of production activities, the scale of the 
financial results achieved and the factors that influenced them, the rationality of use of enterprise resources [1], [2], [3], [4], [ 5], [6], [7], [14]. For a legal service enterprise, these assessments are also necessary, but they will not allow a systematic analysis of all aspects of economic activity, since they are based on quantitative indicators of the expenditure of financial and material resources, equipment performance and other assessments of economic processes that have little effect on the results of work in the legal field. It is necessary to consider the specifics of legal services, clarify and supplement the existing methods of business valuation, which is based on use of intangible assets. Therefore, it is quite natural that in the scientific references the problems of poor knowledge of economic activity in the legal sphere are considered, the importance of formation of new methods of economic analysis of the sphere of legal services is emphasized [20], [24], [28].

Connection between the skill of the service provider and its quality is obvious, but for the sphere of legal services, both of these characteristics of the service are difficult to measure [12], [13]. Thus, assessment of the quality and results of services in the most complex type of legal services - litigation - cannot always be carried out from the standpoint of analyzing the degree of customer satisfaction from provision of services. An expert professional analysis of all aspects of provision of services can be an assessment of the quality of a lawyer's work in the process of litigation, but such an analysis is complex and requires an individual approach to each case, which makes it difficult to formalize and use it to assess the quality of legal services.

The complexity of assessing the quality of provision of legal services in the event of litigation shall not impede the consideration of legal innovations, which act as an independent criterion for assessing the competence of specialists providing legal services.

Legal innovations achieved in the process of litigation not only change the legal status of the parties to the dispute, but also affect the entire legal field. This is an extremely important result, which is noted in legal sciences, but it shall also be considered when assessing the level of services provided by a legal service company, since the organization's ability to influence the entire legal environment highly characterizes its business reputation and competence, creates competitive advantages. Therefore, if a legal service company took part in development of a court decision that is significant for the law, then this can be considered as evidence of its high competence, and the decision itself (or another significant legal fact) can be designated as a legal innovation and be considered as an independent result of the enterprise's work.

In a word, the work of an enterprise to achieve legal innovations, support for the functioning of the lawmaking channel is an important socio-economic result of the activity of a legal service enterprise, which characterizes it highly. Participation in development of legal innovation can be considered as the highest characteristic of the qualifications and abilities of a legal service company. Therefore, it is necessary to evaluate the results of the work of a legal service enterprise considering its ability to act as an element of the mechanism of normative legal regulation, influencing the relations of subjects of law in order to regulate them. Legal innovations as a result of the work of a legal service enterprise shall be considered not only from the point of view of assessing the qualifications of specialists, but also from the standpoint of the orientation of the management of the enterprise's economic activities towards achieving professional heights, which requires appropriate resource support and analysis of all aspects of production and commercial activities.

In the field of law, there is a discussion about how exactly legal innovations are formed, how they are expressed. From the point of view of assessing the reputation-competent capital, it is important to participate in the process of forming legal innovations, which shall be assessed as innovative results of the work of a legal service enterprise.

Use of conditional scores in points allows to form an assessment of such participation 
and reflect it in the index of the reputation and competence capital of the legal service enterprise.

Clarification of the composition and structure of the results of the work of the legal service enterprise considering the influence on these results of reputation and competence capital, is the basis for finding the optimal composition of measures to expand the assets of this type of capital.

The following actions are considered as the main activities that contribute to the expansion of reputation and competence capital: development of regulatory and reference support, expansion of the fleet of communication and computing equipment, strengthening of discipline, professional development of specialists, expansion of cooperation with experts in the field of law.

Increasing capital in all of these areas requires, as a rule, significant costs [25]. Financing such costs from our own sources of funds can be difficult, as well as attracting credit or other third-party resources, since intangible assets are acquired that cannot act as collateral and be considered as a means of securing the return of borrowed funds. Therefore, with a limited budget, it is necessary to form such a set of measures to expand the reputation and competence capital, which, at the lowest cost, will ensure the greatest efficiency of the invested funds.

To carry out such an assessment, the costs of improving the existing technology of activity are compared with the expected change in the service process: reducing the time for providing services, improving their quality, reducing costs. These techniques are widely used to improve the management of various service enterprises (including among business service enterprises), but are extremely poorly used in the field of legal services. Insufficient organizational and analytical support of economic activity in the legal sphere is considered as one of the reasons for this situation [8].

Formation of the category of "legal service enterprise" and allocation of reputation and competence capital as a key asset in provision of legal services are aimed at expanding the methodology of economic analysis in the field of legal services and at overcoming this lag in analytical support of economic activity in the legal sphere.

\section{Conclusion}

Legal service enterprises differ in their production activities, composition of production factors, cost structure and results from enterprises in other sectors of the economy. Personnel qualifications, experience in solving legal problems, techniques and methods of working with customers play a special role in the work of legal service enterprises. These parameters are difficult to measure and consider. Most of the methods of modern economic analysis are aimed at assessing the effectiveness of use of material resources, equipment, financial resources, labor costs. The efficiency of economic activity is assessed by a set of financial indicators. However, the financial indicators of economic activity poorly characterize the current state and prospects for development of activities for provision of legal services, since they do not fully reflect the key characteristics of enterprises of this type, first of all, their competence parameters. So, legal service enterprises can implement massively demanded standard services (for example, for registration or preparation of standard documents) and receive a stable high income. Wherein, specialists who provide highly qualified assistance cannot always receive a stable decent remuneration, which does not allow a full comparison of the activities of various law firms based on a comparison of their financial indicators. To carry out such an analysis and comparison, it is necessary to develop multifaceted indicators that consider the production, organizational, technical, qualification, information capabilities of legal enterprises.

Use of multifaceted assessments of the activities of legal service enterprises allows not 
only to draw up a full-fledged description of their functioning, but also reveals the role and value of those assets of the enterprise that ensure its high competence in the legal field and a stable reputation among consumers and colleagues. These assets are allocated in an independent type of capital - reputation and competence, which is formed by tangible and intangible means that provide a high level of legal services, the achievement of legal innovations, a high degree of consumer satisfaction with the services provided. The concept of reputation and competence capital is based on theoretical and methodological approaches to the study of the intellectual capital of an enterprise, the allocation of goodwill of the company, and on the methodology for forming estimates of the intangible assets of an enterprise. Complementing and expanding these approaches, a system of analysis of reputation and competence capital is formed, which is considered as the main object of economic analysis in the study of the economic activity of legal service enterprises.

The methodological basis for assessing the reputation and competence capital is the techniques and methods of goodwill analysis, which are widely presented in the scientific references. So, for the assessment of intangible assets of this type, relative comparisons are widely used using scores and ratings. Based on the existing techniques, it is offered to form a system of indicators for the analysis of reputation and competence capital by groups: organizational and technical characteristics; competence parameters; reputation and image capabilities of the enterprise; indicators of assessments of reputation and competence capital. The indicators of each group are adapted to the activities of the legal service enterprise, which made it possible to form a methodology for rating assessments that combine the financial indicators of the activities of legal service companies and the characteristics of their reputation and competence capital.

Allocation of reputation and competence capital as a key asset of a legal service enterprise sets as the most important task of managing an enterprise of this type to make investments in increasing capital. Measuring reputation and competence capital allows to choose the best investment option with a limited development budget. Selection process is based on a comparative assessment of the degree of increase in reputation and competence capital when investing only in certain types of assets, which allows to consistently increase capital from the company's own funds, without resorting to credit resources, access to which is quite difficult for legal enterprises that do not have significant material values that can act as collateral for a credit. Wherein, the development of an enterprise is necessary to ensure a stable position in the market and a consistent development policy shall be based on a clear understanding of the role and importance of reputation-competence capital, planning and implementation of measures to increase it.

Implementation of the offered recommendations helps to improve the quality of management of law firms, stimulates the expansion of the range of legal services provided, and also affects development of the regulatory framework of modern society, which is one of the most important aspects of stable and dynamic development, is a condition for formation of effective and modern institutions of economic growth.

\section{References}

1. I. T. Abdukarimov, M. V. Bespalov, Finansovo-ekonomicheskiy analiz khozyaystvennoy deyatel'nosti kommercheskikh organizatsiy (2012)

2. M. I. Bakanov, M. V. Mel'nik, A. D. Sheremet, Teoriya ekonomicheskogo analiza (2005)

3. I. T. Balabanov, Finansovyy analiz i planirovaniye khozyaystvuyushchego sub"yekta, (2002) 
4. M. V. Bespalov, Kompleksnyy analiz finansovoy ustoychivosti kompanii: koeffitsiyentnyy, ekspertnyy, faktornyy i indikatornyy, Finansovyy vestnik: finansy, nalogi, strakhovaniye, bukhgalterskiy uchet, 5 (2011)

5. L. N. Usenko, Yu.G. Chernysheva, L. V. Goncharova, Biznes-analiz deyatel'nosti organizatsii (2013)

6. R. P. Bulyga, Audit nematerial'nykh aktivov kommercheskoy organizatsii. Pravovyye, uchetnyye i metodologicheskiye aspekty (2008)

7. A. S. Vartanov, Ekonomicheskaya diagnostika deyatel'nosti predpriyatiya: organizatsiya i metodologiya (2014)

8. S. P. Goncharov, Yu. K. Yakovleva, Kontseptual'naya model' strategii razvitiya predprinimatel'stva $v$ sfere yuridicheskikh uslug, Innovatsionnoye razvitiye ekonomiki, 2 (50), 304-309 (2019)

9. O. I. Kalinskiy, Rekomendatsii po vnedreniyu modeli upravleniya delovoy reputatsiyey (gudvillom) na promyshlennykh predpriyatiyakh, Upravlencheskoye konsul'tirovaniye, 4 (112), 71-84 (2018)

10. A. V. Korotkevich, Korporativnaya kul'tura kak osnova reputatsionnogo kapitala: metodologiya postroyeniya, metody novyye $i$ formy vozdeystviya, Marketing i marketingovyye issledovaniya, 4 (2008)

11. L. P. Mokrova, I. V. Kosorukova, Instrumenty upravleniya delovoy reputatsiyey biznes $i$ yeye stoimost', Imushchestvennyye otnosheniya v Rossiyskoy Federatsii, 9 (204), 18 31 (2018)

12. Ye. V. Nakushnova, Kriterii kachestva yuridicheskikh uslug, Sovremennoye pravo, 9 (2013)

13. A. A. Svistunov, I. S. Shchepanskiy, T. B. Kulikova, Zarubezhnyy i otechestvennyy opyt otsenki kvalifikatsii yuristov (2018)

14. I. N. Chuyev, Kompleksnyy ekonomicheskiy analiz finansovo-khozyaystvennoy deyatel'nosti (2013)

15. B. Ngwenya, Intellectual capital's leverage on shareholder value growth: a lesson for developing economies, American Journal of Educational Research, 1(5),149-155 (2013). Access mode: https://doi.org/10.12691/education-1-5-1

16. N. Bontis, C. W. Choo, The strategic management of intellectual capital and organizational knowledge (2002)

17. R. Burke, G. Martin, C. Cooper, Corporate reputation: managing opportunities and threats (2012)

18. R. Bushman, E. Engel, A. Smith, An analysis of the relation between the stewardship and valuation roles of earnings, Journal of Accounting Research, 44 (1), 53-83 (2006). Access mode: https://doi.org/10.1111/j.1475-679X.2006.00192.X

19. Y. Ding, J. Richard, H. Stolowy, Towards an understanding of the phases of goodwill accounting in four Western capitalist countries. From stakeholder model to shareholder model, Accounting, organizations and society, 33(7-8), 718-755 (2008). Access mode: https://doi.org/10.2139/ssrn.1000735

20. E. B. Junqueira, Brazil: The Road of Conflict Bound for Total Justice. Legal culture in the age of globalization: Latin America and Latin Europe, Stanford: Stanford University Press, XVIII, 64-107 (2003)

21. C. J. Fombrun, Reputation: Realizing Value from the Corporate Image (1996) 
22. S. Ibraimi, G. Rexhepi, The link between intellectual capital, strategy and entrepreneurship, SSRN Electronic Journal (2011). Access mode: https://doi.org/10.2139/ssrn.1929078

23. R. Jenning, J. Robinson, R. B. Thompson, L. Duwall, The relation between accounting goodwill numbers and equity values, Journal of Business Finance \& Accounting, 23(4), 513 (1996). Access mode: https://doi.org/10.1111/j.1468-5957.1996.tb01024.x

24. M. H. Trotter, Profit and the Practice of Law: What's Happened to the Legal Profession. Athens (1997)

25. A. Mohnen, M. Bareket, Performance measurement for investment decisions under capital constraints, Review of Accounting Studies, 12, 1-22 (2007). Access mode: https://doi.org/10.1007/s11142-006-9020-1

26. R. Moro, Goodwill valuation, The Valuation of Digital Intangibles, 425-448 (2020). Access mode: https://doi.org/10.1007/978-3-030-36918-7 17

27. T. Pfeiffer, G. Schneider, Residual income-based compensation plans for controlling investment decisions, Management Science, 53(3), 495-507 (2007). https://doi.org/10.1287/mnsc.1060.0631

28. A. Pinnington, J. T. Gray, The global restructuring of legal services work? A study of the internationalisation of Australian law firms, International Journal of the Legal Profession, 14(2), 147-172 (2007). Access mode: https://doi.org/10.1080/09695950701616515

29. J. Roos, S. Pike, L. Fernstrom, Managing Intellectual: Capital in Practice (2006). Access mode: https://doi.org/10.4324/9780080479118

30. A. Schueler, S. Krotter, The link between residual income and value created for levered firms: A note, Management Accounting Research, 19(3), 270-277 (2009). Access mode: https://doi.org/10.1016/j.mar.2008.02.003

31. J. M. Skaikh, Measuring and reporting of intellectual capital performance analysis, The Journal of American Academy of Business, Cambridge, 439-448 (2004)

32. S. Sudarsanam, Creating value from mergers and acquisitions: the challenges. An integrated and international perspective (2003)

33. J. Tirole, A theory of collective reputations (with applications to the persistence of corruption and to firm quality), The Review of Economic Studies. Oxford University Press, 63(1) (1996). Access mode: https://doi.org/10.2307/2298112 